\title{
Christianity and the African traditional religion(s): The postcolonial round of engagement
}

\author{
Author: \\ David T. Adamo ${ }^{1}$ \\ Affiliation: \\ ${ }^{1}$ Research Associate, \\ Department of Old \\ Testament Science, \\ University of Pretoria, \\ South Africa \\ Correspondence to: \\ David Adamo \\ Email: \\ adamodt@yahoo.com \\ Postal address: \\ Private bag X20 Hatfield, \\ Pretoria 0028, South Africa \\ Dates: \\ Received: 06 Oct. 2009 \\ Accepted: 11 May 2011 \\ Published: 31 Oct. 2011 \\ How to cite this article: \\ Adamo, D.T., 2011, \\ 'Christianity and the African \\ traditional religion(s): \\ The postcolonial round of \\ engagement', Verbum et \\ Ecclesia 32(1), Art. \#285, \\ 10 pages. doi:10.4102/ \\ ve.v32i1.285

\section{Note:} \\ This paper was originally \\ presented at the World \\ Reform Fellowship \\ Conference, Krugersdorp \\ (Agterberg Center), South \\ Africa, 23-25 September \\ 2008.
}

This article concerned itself with the modern encounter between Christianity and African Indigenous Religion (AIR) in Africa. It is essentially a postcolonial approach to what AIR and its essential characteristics is: God and humanity, sacrifices, afterlife and ancestors. The rapid growth of many religions in Africa and the revival of AIR in postcolonial Africa have made inter-religious dialogue an urgent necessity. Unlike the colonial encounter with AIR, which was characterised by hostility and the condemnation of AIR, the postcolonial encounter should be characterised by mutual respect, understanding, tolerance, and some level of freedom, liberation and genuineness. In this way, suspicion will be reduced, because despite the adherents' confession of Christianity, AIR is not about to be extinct.

\section{Introduction}

The theme of Christianity and its relation with other religions is indeed a delicate issue and must be handled with care. At present, there is no excuse for avoiding it. Needless to say, it is a topic to be explored and carefully mapped out, if illusion is to be dispelled, suspicion removed and conflict minimised.

There is an urgent need for dialogue between Christianity and African Indigenous Religion (AIR), because the present version of Christianity and the increase in the membership of AIR is alarming. The missionary version of Christianity accepted by Africans can be described as hypocritical because many African Christians still patronises AIR, especially in times of emergency. This means that the influence of AIR is still strong, especially in moment of crisis (Mercado 2004, 2005:104). Even today, many who claimed conversion to Christianity still patronises priests of AIR. A former missionary who visited Nigeria, Harry Sawyer, reported that:

I have never been able to see any actual performance, but one night, travelling by car up to the college on Mount Auroel, after the midnight hour, my wife and I encountered a woman performing strange antics in the middle of the road just above a second crossroad. She dashed into the tall grass to avoid detection, but we identified her before she vanished. She was a regular professing Christian.

(Dickson \& Ellingworth 1969:59)

In addition, the description of Bascom and Herskovits (1959) is still correct when they say:

Despite the intensity of Christian missionary effort and the thousand years of Muslim proselytising which have marked the various parts of Africa, African religions contiued to manifest vitality everywhere. This is to be seen in worship of African deities, the homage to ancestors, and the recourse to divination, magic, and other rituals ....

(Bascom \& Herskovits 1959:3)

Mbiti testified to this fact when he stated that 'many millions of Africans are followers of more than one religion, even if they may register or be counted in census as adherents of only one religion is correct' (Mbiti 1975:30). In fact, a local chief of Degubi village in Borno State in Nigeria used to take part in the Christmas celebration and the Muslim Id Al-Fitri, as well as sponsoring the traditional Barrakau [a local celebration] festival (Hickey 1985:218).

According to Philippe, the situation of the encounter of Christianity and AIR is not all that different in South Africa. In the period of Apartheid South Africa, AIR was widely practised, although in secret. The reason for the secret practice was that the missionaries, by the 19th century, 'whether they were Congregational, Methodist, Anglican and Lutheran or, Catholic, were aggressively opposed to traditional African practices that they considered barbaric and based on superstition' (Denis 2006:310-323; Mills 1995:153-172). By the 20th century, AIR and its practices were still not well thought of by White people in South Africa; however, despite the condemnation, AIR continues to be practiced even in the present.

In the post-Apartheid period, there is a record increase in the practice of AIR in South Africa. Since the birth of democracy in South Africa, this religion has occupied an important position 
in public life (Denis 2006:310-323). Similar to Nigeria after independence, AIR has become an essential element of indigenous knowledge systems; several steps have been taken by health workers and in Parliament to give recognition to African indigenous healers and Christian churches in South Africa openly advocate dialogue with AIR (Denis 2006:310-323).

This article discusses briefly what postcolonialism and the meaning of AIR and its encounter with Christianity are. Different levels of interreligious dialogue and its obstacles will be discussed. More importantly, conditions for having a genuine and successful dialogue between AIR and Christianity are discussed.

\section{What is postcolonialism?}

As early as 1961, Frantz Fanon provided the work that initiated what has become the present postcolonial theory amongst academics by his publication The Wretched of the Earth, which was a sequel to his book Black Skin, White Masks, published in 1952. As a result of this, Dawn Duncan regards Fanon as the father of postcolonial studies (Duncan 2004:1); however, this field gained great prominence in the 1970s when Edward Said produced the first academic book, Orientalism in 1978. The term 'postcolonialism' was consolidated by the appearance of the book, The Empire Writes Back: Theory and Practice in Post-Colonial Literatures by Bill Ashcroft, Gareth Griffiths and Helen Tiffin (1989).

Since then, there has been a general debate as to the precise parameters of the field and exact definition of the term 'postcolonial' or 'postcolonialism'. This is to say that a single definitive definition of postcolonial theory is controversial. Despite a history of definitions and debates, this term remains 'fuzzy concept stretching from a strictly historical definition to the more encompassing and controversial sphere of contemporary key-terms such as post-structuralism, postmodern and the like' (Duncan 2004:2). Literally, it refers to the period of time after colonialism or after independence. According to Helen Tiffins, who was one of the editors of the book The Empire Write Back, postcolonialism refers to the 'writing and reading practices grounded in some form of colonial experience occurring outside Europe but as a consequence of European expansion and exploitation of the other worlds' (Duncan 2004:2). The word 'postcolonial' has been coined to describe modern history of imperialism, colonialism, the struggle for independence, the attainment of independence from the colonial domination and the present neocolonialist realities (Ashcroft, Griffiths \& Tiffin 1989:2; Dube 2000:15).

Defined in a very general sense, it is understood as the study of the interactions between European nations and the societies they colonized in the modern period' (Bahri 1996:1). Postcolonialism can also be defined as the way in which race, ethnicity, culture and human identity itself are represented in the modern era, after many colonised countries gained their independence. Postcolonial theory is concerned with matters of race, ethnicity, gender, with the challenges of formulating a postcolonial national identity. It tries to describe how a colonised people's knowledge was used against them in the service of the coloniser's interests and how knowledge about the world is generated under specific relations between the powerful and the powerless. Postcolonial theory also encourages the creative resistance of the colonised to the coloniser. The theory tries to provide a framework that destabilises dominant discourse in the developed world and challenges 'inherent assumptions' and critiques the 'material discursive legacies of colonialism’ (Bahri 1996:1).

Critically understood, postcolonialism is a hopeful discourse; postcolonialism is decolonisation. The word post means looking forward to a world that may truly move beyond all that is colonialism. It aims at decolonising the future by destabilising the way of thinking of the developed world in order to create space for the subaltern or marginalised groups to speak and produce alternative to dominant discourse. That is the reason why Homi Bhabha defines postcoloniality, postmodernity and postfeminism as the 'terms that insistently gesture to the beyond ...' (Bhabha 1994:4).

Postcolonialism may also designate and denounce the new forms of economic and cultural oppression that have succeeded modern colonialism, which is sometimes called 'neo-colonialism'. It may mean that the so-called cooperation, assistance, modernisation and the likes are new forms of political, cultural domination similar to colonialism or colonial imperialism.

Therefore, the study of religion and religious dialogue under postcolonialism is an attempt to clarify the possibilities and constrains of religion and religious dialogue (Isomae 2006:85). It is also an attempt to approach religions as equally legitimate and participants in inter-religious dialogue as equal partners, unlike during the colonial period when adherents of Christianity considered AIR as inferior religion and members of interreligious dialogue as unequal partners. Mobolaji Idowu in Olodumare: God in Yoruba Belief (1962), African Traditional Religion: A Definition (1973), Omosade Awolalu in Yoruba Belief and Sacrificial Rites and John Mbiti in The Concept of God in Africa (1970) are a few examples of postcolonial scholars of religion who have resisted and denounced colonial idea that Africans do not know God. They counteracted various derogatory names given to AIR.

\section{What is African Traditional Religion(s)?}

Is there anything called African Traditional Religion(s) (ATR) at all? One may be surprised that this question is asked here, because the title of this article is, 'Christianity and African Traditional Religion(s): A postcolonial round of engagement'. During the early days of missionaries, travellers, anthropologists and historians, there was no acceptance of any existence of anything called African history (Fage 1970:1) and ATR(s), despite the fact that they struggled with the adherents of this religion and tried to condemn what 
they thought never existed. Consequently, the one without history cannot have religion (Denis 2006:312). To some anthropologists, 'untutored' Africans cannot know God as the idea of God is philosophical. To the missionaries in the early days, Africans were not fully human; they prohibited polygamy, initiation rites, ancestor worship and other indigenous practices (Mercado 2004, 2005:99).

In this postcolonial period, it has come to be established that there is what we may call $\operatorname{ATR}(\mathrm{s})$; however, there is no unanimous agreement as to whether it is religions in the plural or religion in the singular. Mbiti believes that it should be religions in the plural (1990:1-3). His reason is that Africans are notoriously religious and there are different beliefs and tradition according to ethnic groups. There are so many ethnic groups as there are many traditional religions (Mbiti 1990:1-3). Furthermore, he argues that AIR does not have one origin or one historic movement and that the beliefs amongst the different communities differ greatly (Mbiti 1990:3-5). However, Mbiti later accepts the use of AIR in the singular, in the preface of the second edition of his book (1990: 13). He says that 'in the first edition I spoke about "African religions" in the plural to keep alive the diversity of African religiosity ... I now use the singular, "African religion," more than the plural expression' (Mbiti 1990:13).

However, Idowu argues for the singular use, because of the common racial origin of the Africans and the similarities of their culture and religious beliefs (Idowu 1973:103-104). Because the real cohesive factor in religion in Africa is the living God, it is should be African religion instead of religions. Shorter (1975) believes that we can speak of the African religion in the singular, because of the basic unity of African religious systems:

\begin{abstract}
Although they (African religious systems) were separate and self contained systems, they interact with one another and influenced one another to different degrees. This justifies our using the term African Traditional Religion in the singular to refer to the whole African religious phenomena, even if we are, in fact, dealing with multiplicity of theologies.
\end{abstract}

(Shorter 1975:1)

Another problem is the appropriate title of the very indigenous religion of Africa. This author is one of the African indigenous scholars who are not at home with the title ATR(s). The quarrel is the word 'traditional' and 'indigenous' instead of 'traditional' is preferred, the reason being that 'traditional' does not necessarily mean indigenous. Tradition can mean:

a belief, custom or way of doing what has existed for a long time amongst a particular group of people and not necessarily inborn or aboriginal; a set of these beliefs or customs.

\section{(Oxford Dictionary 2000:1271)}

Indigenous, on the other hand, means 'aboriginal, homegrown, inborn, inherent, native' (Websters Dictionary 2005:609), 'belonging to a particular place rather than coming to it from somewhere else' (Oxford Advance Dictionary 2000:609). From the above definitions, it is preferred to call it the indigenous religion of Africa (AIR) in the singular. This is because AIR is one religion with different versions from one country to another in the African continent, just as Christianity has different denominations and versions with a variety of practices all over the world.

What is AIR? It can be defined as the inborn and aboriginal religion of Africans, embraced by the forefathers of the present generations. It is described as the religion that emerged from the sustaining faith of the forebears of the present generation of Africans passed from generation to generations and still practiced today by the present generation of Africans (Awolalu 1991:111). It is the religion without a founder, as 'the founders cannot be found no matter how far we go back to history' (Awolalu 1991:111). AIR is the belief of the forefathers on the existence of the Supreme God, divinities, Spirit beings, Ancestors and mysterious powers, good and evil and the afterlife. These are the essential characteristics of AIR, which will be explained further to assist in making clear its meaning.

\section{Essential characteristics of African Indigenous Religion}

The main feature of AIR is the whole of the African worldview, which forms the essential characteristics. One of the best ways of starting authentic dialogue with AIR is to have a sound knowledge of the central themes of the African worldview, together with the people's problems, needs and aspirations (Nyamiti 1994:68).

\section{The supreme God and human beings}

The first and central amongst the themes in AIR is God and human beings. The basic structure of AIR amongst the Yoruba people of Nigeria has the Supreme Being as the head of all things, the creator (Van der Walt 2003:63) and the controller, the everlasting, the omnipresent, omniscient, omnipotent and ever-acting God, even if all divinities and the ancestors became silent. Like in the Old Testament, the basic belief in the Supreme Being, God, is not disputed all over Africa. He is the unique and the incomparable one. B.J van der Walt's diagram has the Supreme Being as the head and the rest of the spirit world and human community follow him (Van der Walt 2003:64).

The concept of human beings in AIR is also important, because it is generally acknowledged that God is the originator of humanity, despite the fact that the exact method of that creation may be different from place to place (Mbiti 1990:120; Muzorewa 1985:16-17). To be a human being is to share a sense of a community. What makes a human being is incorporated in the 'complex unity of the tribe, outside of which all others are strangers and inferiors, if not enemies' (Sidhom 1969:99). This relationship can be extended to the invisible world, the spirit world in all the hierarchical order, namely God, Deity and Ancestors (Oborji 2002:17). When there is estrangement between God and the spirit beings, there is a need to pacify and recapture the lost relationship between God and humankind by sacrifice, performing rituals and medicine (Orji 2002:18). 


\section{The divinities}

The next in rank to the Supreme Being, God, are the divinities. The divinities are brought to life by the Supreme Being. Amongst the Yoruba people of Nigeria, Orisa-nla is one of the divinities and the next in rank to God, but created by God, who left the universe in their hands to be refashioned. All the divinities are functionaries and act as intermediaries between the Supreme Being and the rest of the universe, including human beings. They have no power of their own, except what the Supreme Being permits them to do. Yet they are very important as far as the orderly function of the universe is concerned.

\section{Ancestor veneration}

The final end and the aspiration of each and every person is to reach the spirit world of one's ancestors, to be venerated by one's descendants as an ancestor and eventually be reincarnated (Oborji 2002:24); therefore, ancestors are people who have made it to the spirit land and are venerated by their descendants. They are regarded as part of the elders of the families with enhanced powers to bless, protect or punish the families. They are invoked to share at gatherings, ceremonies and ritual communion and are seen as symbol of peace, unity and prosperity in the family. The ancestors are not worshipped, but highly respected as members of the families. They are next to the divinities in the hierarchy (Oborji 2002:24). Ancestors act as intermediaries between God and the members of their families.

\section{Spirits}

Spirits are the next in hierarchy. Spirits, according to African belief are 'apparitional entities', which belong to different categories of beings than the divinities. Spirits are anthropomorphically conceived as if they are abstract beings. It is believed that they are capable of becoming anything, such as objects or human beings and can also melt into vapour at any time (Adamo 1983:66). In AIR, it is generally believed that everything has spirits and that these spirits also have categories. There are ghost-spirits, born-to-die spirits, generally called abiku amongst the Yoruba people of Nigeria, spirits of witches, the guardian spirits and diviner spirits. Belief in these spirits permeates the life of Africans and should be taken seriously. In the Yoruba traditional belief, the above structure is real (Olupona \& Rey 2008:94).

\section{Good and evil}

In AIR, the existence of good and evil is real. Evil in AIR includes both physical and moral evil. God is the one who brings forth good, but human being causes evil to themselves and others. Evil concerns any misfortune that befalls an individual or community or any voluntary antisocial behaviour or any infringement of the decrees of God, the deity or the ancestors. Evil is generally interpreted as the work of evil spirits, witches, sorcerers or evil eye, broken taboos, oaths or even the deity or ancestors. It is also believed that usually when God or deities or ancestors are involved in evil, it is corrective, disciplinary, or punitive.

\section{Sacrifices}

As discussed previously, adherents of AIR are concerned not only with the causes of evil, but also have to deal with evil. Propitiatory sacrifices become one of the major ways by which Africans deliver themselves from the effects of evil in the world. Whilst sacrifices involve the offering of blood, whether that of a human being, animals or birds, offerings do not involve blood, but the giving of other gifts such as food, oil, water, yam, milk, honey, money and others. When blood is involved in making a sacrifice, it means that the purpose must be serious. Sacrifices may be a means of restoring fellowship with God, gods, ancestors and the environment. According to Ikenga-Metuh, there are only two classifications of the aim of sacrifices in AIR. Firstly, there are sacrifices with positive aim of actualising in nature and amongst men, the abiding and self-subsistent divine life. Secondly, sacrifices with negative aim, atoning sacrifices or peace offering in order to ward off danger of false piety, so as to cause sicknesses to cease (Ikenga-Metuh 1991:80).

\section{The afterlife and the final end}

The central motivation in AIR is the quest for life and its security. This is because life in African indigenous tradition is conceived as continuum, with a dynamism of rhythm and circles that follows the process of birth, death and rebirth. What is of paramount interest is that people can still have access to the eschatological realm of existence through rituals by invoking the powers of divinities to renew and revitalise their potentials, so as to put right any broken relationship during their life time. People's hope is to join the rank of the ancestors in the spirit world, with all its rights and benefits and used their enhanced powers for the benefit of their families and clans (Ikenga-Metuh 1987:262).

Life is also conceived as communion and is not limited only to the relationship with the created order, the universe, the spirits, ancestors, one's family and community, but also with the Creator God. However, the most loathsome expectation in the afterlife is to end up as wandering spirit, vagabond, cut-off from the community and one's family (Oborji 2002:23). This actually means that in AIR, there is an afterlife that has to do with the continuing relationship of the dead with the living, but not as the final end of humanity or the world (Ikenga-Metuh 1987:263).

\section{Salvation in African Indigenous Religion}

From the previous description of the nature and characteristics of AIR, the question still remains whether there is any value of salvation in AIR? To put the question in a different way, is salvation possible outside the visible institutional church? This is an important question, because the merit of any serious religion depends on whether it can bring salvation to its adherent or not. The answer to the question has been a great problem in the effort of the church to dialogue with AIR. To understand the answer to this question, some preliminary considerations are important. 
The first preliminary statement on the salvation in AIR starts with humanity's basic equality before God. It means that God is present within the whole of mankind, of course, in different ways whether through the agency of the law or through the working of conscience for the other. All people are subject to sin and God's wrath just as all are opened to the saving grace of God.

The second preliminary statement is the existence of a cosmic covenant of love between God and mankind by creation (Genesis). Humankind may break this covenant through sin and infidelity, but again and again God renews it and reaffirms his salvation intention to all mankind (Kalilombe 1981:62-63). His special choice of Israelites and the church did not abolish that cosmic covenant made with humankind.

The third preliminary statement is that in all serious efforts of humankind to make sense or respond to God's cosmic presence and cosmic covenant in life and destiny, God has been in and with his peoples. In other words, the spirit of God has indeed filled the whole earth.

From all the preliminary statements above, one will be correct to say that African religious systems of ancestors were not merely tolerated by God; 'they were the results of efforts of African cultures wherein the Spirit of God was an active agent' (Kalilombe 1981:67). The fact is that AIR has been a medium, through which God has been communicating with the traditional Africans until the advent of Christianity (Kalilombe 1981:65). Therefore, AIR is based on that revelation and according to Oborji, it is also based on the Africans' pre-Christian idea of salvation and the security of life and a religion on quest for long life (Oborji 2002:28). Oborji (2002) described salvation in AIR:

The final end and the aspiration of all, every person, is to reach the spirit-land of the one's ancestor, to be venerated by one's descendants as an ancestor, and eventually (at least in some traditions) to be reincarnated. Ancestors therefore, are people who have made it to the Spirit land and being venerated by their descendants. The ancestors are not worshipped by the Africans; rather they are regarded as the elder members of the family. As spirits, they have enhanced powers which they are believed to use mainly to protect the interest of their families, or clan. In the hierarchy of beings, after the Supreme Being and the deities, come the ancestors.

(Oborji 2002:24)

Death is not the only requirement for achieving salvation or attaining the position of ancestors. Old age, life lived very well according to the accepted standard of the group, offspring and appropriate funeral ritual are other important requirements for the salvation (Mbiti 1991:68-69). The highest one can hope for at death in AIR, is ancestral communion, life in the spirit-world of ancestors (Oborji 2002:29). This might be one of the reasons why Vatican II answer the question affirmatively that:

Those also can attain to everlasting salvation who through no fault of their own do not know the gospel of Christ or His Church, yet sincerely seek God and, moved by grace, strive by their deeds to do His will as it is known to them through the dictates of conscience.

(Kalilombe 1981:51)

\section{What is dialogue?}

What is dialogue? Religious dialogue means the exchange of views and insights by means of concepts expressed in words that are based on previous agreement concerning the common, which the dialogue thereafter tries to widen and deepen, so as to pinpoint divergences, similarities, complementarities, and criticisms, as well as to find the loci where mutual influence or fecundation may take place (Panikkar 1975:407-409). According to the ordinary meaning of dialogue, 'it is a conversation between two people or an exchange of ideas and opinions' (Adamo 1989:82-88). In ecumenical context, dialogue is more than a conversation or exchange of ideas or opinion. It means the sharing of religious conviction for the purpose of mutual understanding that will eventually result in 'a peaceful co-existence amongst world community of various religious faith' (Adamo 1989:82-88).

There are different levels of dialogue enumerated by Gort (2008:758-760). The first level of inter-religious dialogue is what may be called 'the dialogue of histories' (Gort 2008:758). This type of dialogue begins with a serious analysis of the past relations between the religions involved, in order to know what stance and respect they have for one another. The position they occupy vis-à-vis each other on the political, social and economic planes so that at this level questions of justice, injustice, power, domination, wealth and poverty is discussed and ironed out.

The second level of inter-religious dialogue is 'the dialogue of theologies' (Gort 2008:758). The purpose of this type of dialogue is to remove inter-religious nescience and misunderstanding, so as to foster respect and tolerance amongst participants. Every participant recognises the right of the others to deny and contradict the truth to which they hold and to speak their own mind (Gort 2008:758). This level of dialogue is to gain a sense of the deepest meaning and intention of one another's religious tenet and thus, a way of breaking through communalist apprehensions of religion (Gort 2008:760).

The third level of dialogue, according to Gort, is 'the dialogue of spiritualities'. This is the means of talking heart to heart about their deepest fears and highest hopes, desiring to understand and to be understood, in order to effect a respectable exchange of truth-claims, core beliefs and convictions and existential religious feelings (Gort 2008:760; Wijsen 2007:171). There would be the opportunity to share spiritualities of reconciliation.

The fourth level of inter-religious discourse is 'the dialogue of life' (Gort 2008:760). Apart from the theological and spiritual differences and concerns, there are concerns of life. Such concerns of life have to do with injustice, poverty, hunger and others. Wijsen puts it right when he says 'interreligious dialogue ... cannot confine itself to the problem of pluralism', but also with 'domination and the problem of poverty' (Wijsen 2007:188). 


\section{A brief history of dialogue between African Indigenous Religion and Christianity}

Christianity from its earliest history has maintained a negative attitude toward other religious traditions such as African and Asian religions. As early as the period of Cyprian of Carthage (258), he maintained vehemently that there was no salvation outside the Christian church (Gort 2008:748). He wrote that 'he cannot have God for his Father who does not have the church for his mother' (cited by Gort 2008:748). The religions of other cultures were viewed as 'non-Christian'. They were perceived as expressions of 'heathen unbelief and evil superstition' and the world outside the church came to be seen as the 'kingdom of darkness' (Gort 2008:748).

Although for the next 1500 years or more, what Christians thought of other religious tradition was governed by the above perception, there existed those few who challenged the prevailing thought and advocated a more accommodating model of encounter with other religions. Pope Gregory the Great (c. 540-604), Raymond Lull (c. 1235-1315), Bartholomew de las Casas (1474-1566), Matteo Ricci (1552-1610) and Robert de Nobili (1577-1656) were some of the few who preached accommodation (Gort 2008:749). Unfortunately, such protests went unabated up to the modern time and the missionary attitudes were still guided by 'unbridled feelings of superiority'.

However, since the 1930s, Christianity has become more open towards other religions. In 1934, the Negritude movement promoted the elevation of AIR. After World War II, the Negritude movement was organised into the Societe Africaine de Culturen [African society of culture]. Societe Africain de Culture organised two congresses of Black writers and artists, where their leaders were trained to work with people of different religious beliefs and to take seriously AIR in particular. Even though Societe Africaine de Culture was not a religious organisation, it was an organisation where people of religious beliefs could gather as equals, thus preparing the background for dialogue amongst Christianity, Islam and AIR (Nkulu-Sengha 1996:535).

There has been inter-religious grassroots dialogue since the arrival of Christianity and Islam in Nigeria. When brothers of the same family embraced two different religious beliefs, they were forced to interact. For example, whenever there is a celebration either amongst the Muslims or Christians or AIR, they celebrated together without contradiction. An example was in 1969 in Kampala, where Muslims assisted at the blessing of the cornerstone of the Basilica of the Martyrs in Uganda by Pope Paul VI.

The creation of the Ecumenical Association of Third World Theologians (EATWOT) in Dar-es-Salaam, Tanzania, in 1976 increased the awareness of the importance of inter-religious dialogue. This enabled African churches to be in dialogue not only with AIR, but also with Islam. African theologians were also in dialogue not only with churches in Africa but also with the international community.
The Association Occumenique des Theologiens Africains [Ecumenical association of African theologians] (AOTA) was created in Accra, Ghana as a subsection of EATWOT in 1977. Since then, AOTA, which described itself as ecumenical association, has been in the business of making African theologians in dialogue with different churches not only in Africa but also in other continents. It means that they have created an interaction between Africa and international community on the issue of inter-religious dialogue (NkuluN'sengha 1996:536). At present, AOTA is still fostering interreligious dialogue at the academic level in Africa.

The affirmation of the declaration of the Fundamental Human Right by the United Nation Organization (OAU) and Organisation of African Unity (OAU), which condemn any discrimination based on religion has assisted in promoting the consciousness of 'equality' amongst believers of different religious adherent.

Between 1945 and 1965, the African elites emphasised that political independence must go hand in hand with religious independence and that colonial mentality must change regarding AIR and Christianity. In 1963, the African Society of Culture was organised. In 1966, the Vatican document, Ecclesiae sanctae [the holy church], called for a setting up of study groups to study AIR. Whilst there were responses throughout Africa, the most impressive response to this call came from Zaire, where as early as 1967, Vincent Mulago established a centre for research on AIR at the Catholic Faculty of Theology. The centre published several books and organised international symposia. Pope John Paul also changed the name of the Secretariat that was called 'NonChristian Religions' that was set up in 1967, to Pontifical Council for Interreligious Dialogue, to avoid the negative implication of the name 'Non-Christian'. In 1970, two important symposia were held on 'Traditional African Religion as a source of civilization values' (Nkulu-Sengha 1996:533). Many African intellectuals from various religious backgrounds were present to define AIR as the foundation of Black culture. It was also emphasised that AIR constitutes an important bridge between the African people outside religions such as Christianity and between Islam and Christianity, because it is the deposit of African values and identity. For its spirit of tolerance and lack of missionary agenda, AIR also provides a spirit of cooperation and harmonious living with people of other religions; therefore, it is a good foundation for interreligious dialogue in Africa (Nkulu-Sengha 1996:53).

Pope John II promoted inter-religious dialogue during his pontificate. In 1986, during the Assisi inter-religious prayer meetings for peace, he personally asked for forgiveness for the past mistakes of the church from traditional religious leaders (Mercado 2004, 2005:102). He also intentionally put Cardinal Francis Arinze, the son of a Nigerian chief, to head it (Mercado 2004, 2005:102). Cardinal Arinze wrote a pastoral letter titled 'Attention to African Traditional Religions', which may be the first Vatican document to recognise AIR as a dialogue partner in the African context (Mercado 2004, 
2005:102). In 1988, the Pontifical Council for Interreligious Dialogue issued a letter titled 'Pastoral Attention to A.T.R.' The council was responsible for increased theological research on dialogue with Islam and AIR in Africa.

In 1995, many African Bishops were in Rome for the first African Synod of the Catholic Church ever organised in modern Catholicism (Nkulu-N'Sengha 1996:528-556). The African Synod included in her agenda 'Interreligious dialogue' amongst the top priorities of the Church in Africa. With this, it was noted that the religious situation at the time requires a serious consideration of the condition of the possibility of a genuine interreligious dialogue.

In 1996, at the Catholic Bishop Conference in the Philippines, a series of dialogues with followers of traditional religions were initiated and Archbishop Fernando Capalla also asked for forgiveness from the traditional religious leaders, just as Pope John Paul II did.

Vatican II made possible the dialogue between AIR and Christianity and between Christianity and Islam, by recommending dialogue with non-Christian religions of the world, noting also that there are some lights of truth from the same God, the creator of all people. African theology faculties were established for the purpose of a clear awareness concerning the dialogue with AOR (NkuluN'Sengha 1996:535).

\section{Obstacles to genuine dialogue in Africa}

From my brief review of the nature of AIR and the brief history of the encounter between Christianity and AIR, one can truly observe the following as the main obstacles to dialogue between AIR and Christianity.

Firstly, there is hostility on the part of Christianity against AIR. This is as a result of inherited prejudices developed by past colonial theology and the feeling of superiority over against 'primitive religion of animism and polytheism'. AIR is called the 'empire Satan'. They were labelled 'pagans', 'heathens', 'idolatrous', 'polytheist', 'barbarians', 'superstitious', 'fetishists', 'primitive' (Mercado 2004, 2005:93-104). To some Christians, AIR is synonymous to misery and superstitions. Shorter (1991) described such attitude of Christians to dialogue with AIR:

The churches in Sub-Sahara Africa could afford to ignore Islam, as long as Muslims were backward ... Christians could also afford to antagonize the adherents of ATR's. It was felt that they had no future within or outside the Church, and a relentless war of annihilation was fought against them. Dialogue with ATR's appeared laughable under this circumstance.

(Shorter 1991:82)

Secondly, there is ignorance of the exact nature of AIR. The Christian attitude mentioned previously toward AIR brought about serious ignorance on the part of the Christians. As it is a primitive religion, it is not worth studying and therefore not worth dialoguing with.
A third obstacle is Christian and Muslims' aggression toward African Indigenous religion. Both Christianity and Islam are missionary religions; the adherents of these religions are always anxious for conversion and are in competition. Unfortunately, AIR is the target. In Africa, Muslims are struggling to do better than Christians, whilst Christians are struggling to do better than Muslims in converting adherent of AIR, whose religion is not a missionary religion.

Fourthly, there is fear of syncretism on the part of Christians. Many Christian theologians considered dialogue with AIR a step toward syncretism. In fact, the question of inculturation or Africanisation of Christianity is seen as a corruption of Christianity, because Christianity must be Christocentric. As a result, Christian religion is absolutised (Ariarajah 1976:5).

The level of poverty and oppression in Africa raises a fifth serious obstacle to not only a genuine dialogue, but also economic democracy and justice that are badly needed in Africa. The socioeconomic injustice, the violation of human rights and threat to total destruction in Africa threaten peace amongst the people. Where there is no peace, genuine dialogue cannot take place.

Sixthly, fanaticism is an obstacle to genuine dialogue. The truth is that religious fanaticism is not compatible with AIR and culture, because African culture has a great level of religious tolerance. The negative influence of fundamentalism from Asia, America, Europe and other places seem to characterise Christianity, Islam and other religions in Africa.

\section{Towards a genuine dialogue between Christianity and African Indigenous Religion}

There has not been a genuine dialogue between African Indigenious Religion (AIR) and Christianity as a result of the obstacles enumerated previously.

The first important thing to observe in achieving a genuine dialogue, is finding a common ground. Despite the real differences and even disparities between culture and religions, there is a basic stratum of human commonalities that can make it possible for people to communicate with one another and to discover points of contact with others (Gort 2008:756). Such commonality may include common experiences, fears, questions and sorrows that people everywhere share.

For a genuine dialogue to take place, the participants should be concerned with the nature of dialogue. A genuine dialogue with AIR should take the nature of what Knitter calls 'liberative dialogue' (Knitter 1995:218). In this case, the dialogue should start with nonreligious issues, reflecting the existing problems of the community. Such dialogue should include compassion, collaboration, comprehension and conversion (Muwahidah 2008:79-92). As Nkulu-N'Sengsha (1996) states: 
If dialogue hides the real problems that divide people of Africa, and if it does not help them to make their life better and more human, then it is a futile enterprise and even an insult to human intelligence and a crime against humanity.

(Nkulu-N'Sengha 1996:554)

The historical origin of Christianity and AIR may be the common ground for dialogue. The main source of these religions is the belief in God and his attributes. Several scholars have demonstrated the fact that AIR believe in the Supreme God, the creator of the heavens and the earth (Idowu 1962; Awolalu 1979; Mbiti 1970). The question of the attributes of God in AIR and Christianity can be a great place of departure. Holiness, goodness, mercy, immutability, righteousness and others are attributes of God in both religions. That the Supreme Being is the creator and the father of all that exists, that there is unity of life and participation can be a common ground to start a genuine dialogue.

It is a fact that any genuine dialogue, especially religious dialogue, depends on the cultural settings from which the partners speak; therefore, it is imperative not to overlook the cultural differences that are expressed in different religious beliefs if genuine dialogue is to be achieved. It means that the first requirement for a genuine dialogue is to find 'a firm ground where the dialogue itself may take place. Such common ground is the local myth' (Panikkar 1975:407-409).

For a genuine dialogue in Africa, it is absolutely important for the participants to recognise and accept the fact that 'all human life - not just an artificially isolated segment called the "religious life" - and that all human beings - not just Christians - are part of God's activity in the world and share common future' (Ariarajah 1976:3-4). One has to take one's partner seriously and seek to learn from their religious experience. There should be a clear understanding of the nature of the community we seek to dialogue with, because dialogue has to do with the question of the relationship of the Christian community to the human community of which is a part. A genuine dialogue should therefore take the human community as the locus of God's activity.

There must be an equal preparation for the two parties, both theologically and culturally, to avoid misunderstandings by any of the parties.

Mutual trust is also an important requirement to genuine dialogue. Nkulu-N'Sengha has suggested other ways of achieving genuine dialogue with AIR (1996:551-552):

- 'Epistemological metanoia.' That is, all the negative language against the African continent and religion must be put aside to achieve any genuine dialogue. In other words, 'pejorative terminology' must be banished.

- Ethical matters must be at the forefront of genuine interreligious dialogue with AIR. This is because in African culture and religion the concepts of right or wrong are determined by orthopraxy and not by orthodoxy.

- Great attention should be paid to 'popular wisdom'. Unlike dialogue amongst theologians, dialogue at the grassroots level should pay great attention to the popular wisdom that makes the community lives together in peace despite different religious tradition. In Africa, there is a need for the people who want to achieve a genuine dialogue to learn from the people. Despite the different religions amongst the grassroots people in Africa, they know that the types of religious wars of the developed world are not necessary. People of different religions learn to eat together, sleep together, celebrate together and live in peace.

- A reorientation or a revision of 'the theology of missionary activity' and the pretention of Christian missionaries' claim to universality should be revised. Christian missionaries and other indigenous Christians should re-examine their theology of 'absolutism' and embrace what Swidler calls 'Realitology', that is, 'a rational relationality that focuses on the Ultimate Reality without absolutizing its particular expressions'. Christians must be ready to come out the 'Teutonic captivity' of Christian theology, which refuses to break out of the historical cultural framework of the developed world, to which the Word of God in the Bible has been made captive (Ariarajah 1976:4). Scripture should not be a dividing wall.

- An attitude of humility and repentance should be embraced, instead of arrogance in a dialogue that involves many sensitive issues in a community.

- African inculturation theology and African religious tradition and culture should be studied seriously, because they constitute the foundation for the possibility of meaningful interreligious dialogue in Africa.

- Dialogue education should be embraced. This will bring a necessity for the creation of a global interfaith university to be possibly based in Nigeria with campuses in Egypt, South Africa, Zaire, Kenya, Senegal, Tanzania and Cameroun.

- There should be a religious and cultural democracy practiced in Africa. This will enable those involved in genuine dialogue to respect AIR and tradition. It means that there must be a guarantee of freedom, not only of thought, but also of action and consequently, a formation of principle of pluralism.

- Religious and cultural democracy should not be the only thing; human rights, social justice and economic democracy should be practiced in the process of achieving a genuine dialogue with AIR. This will assist in eradicating the culture of domination, oppression, injustice and economic exploitation. Any dialogue that does not focus on peace and the meaning of human life that is the source of conflict cannot be genuine.

\section{Conclusion}

What is the essential purpose of this type of dialogue? Our understanding of each other's faith and convictions will assist us not to disfigure each other's faith and ideologies. Dialogue is a way of obeying one of the commandments given to the Israelites: 'Thou shall not bear false witness against your neighbour' (Ex 20:16). If we do not dialogue, we shall be ignorant of our neighbour's faith and we could therefore misrepresent such faith. 
Dialogue with adherence of African Indigenious Religion (AIR) is a way of expressing our love and concern to our neighbour, which is actually the greatest commandment in the Bible. This means that dialogue without genuine love and concern is not true dialogue. If Christians dialogue with people of AIR, it will mean a proclamation of faith in Christ in the spirit of love. It can also be regarded as 'authentic witness' of one's convictions. In the process of dialogue, essential truth is proclaimed in love (Adamo 1989:82-88), the result of that proclamation should be left to the Holy Spirit, who really converts and not the one who holds the dialogue. The attitude of 'come-ye-outism' in Africa should be gone for good. There is a need to go beyond the dismissiveness, antagonism and intolerance that had in the past characterised Christian attitudes towards other religious community (Hospital 2007:356).

It seems Christianity in Africa has not adequately tapped this resource that can make Christianity authentically African. The challenge is legitimate because the process of indigenising African Christianity still has a long way to go in Africa. In the words of Du Toit, 'Whites must come to grips with the fact that Christianity in South Africa is predominantly a non-Western religion. Western theology, as taught in universities in Africa, serves a minority group of Christians in the country' (1998:38).

$\mathrm{Du}$ Toit maintained that the new openness toward Africa in post-Apartheid society seems to dwindle when it comes to interaction with traditional African Religion especially African spirituality' (Du Toit 1998:36-60). Indigenous African spirituality is an important aspect that Christianity can learn from and make use of. The truth is that 're-encountering Africa is impossible without taking the challenge of African Indigenous Religion and their spirituality very seriously' (Du Toit 1998:36-60).

Admittedly, care must be taken to avoid thinking that African Christianity is the same as AIR and culture. Care must be taken not to turn African Christianity into AIR in the name of indigenising Christianity in Africa. It must be emphasised that it is not all in AIR and culture are good. African Christians must sieve what is bad in African religious tradition and take what is good.

From the previous, one will be right to affirm that the Christian message of life, the eternal life in Christ, have something to offer to the Africans of AIR. If the AIR's sacrifices and veneration are able only to help men and women reach the spirit world in order to be able to continue to participate in the life of the clan and family as an ancestor, the Christian message of eternal life has now perfected and elevated this ancestral level of the spirit world and life to the highest level of the hierarchy of being, namely, participation in the very life of God as such, the Creator of humanity and source of all life (Oborji 2002:28).

\section{References}

Adamo, D.T., 2006, Africa and Africans in the New Testament, University of America Press, Lamhart, MD.
Adamo, D.T., 2001a, Africa and Africans in the Old Testament, Wipf and Stock Publishers, Eugene, OR.

Adamo, D.T., 2001b, Explorations in African Biblical Studies, Wipf and Stock Publishers, Eugene, OR.

Adamo, D.T., 1989, 'Salvation According to Christianity and Buddhism', The Journal of Religious Studies, 17(2), 82-88.

Adamo, D.T., 1983, 'The Church in Africa and African Traditional Religious Beliefs and Practices', Rel. D. dissertation, Indiana Christian University.

Ariarajah, S.W., 1976, 'Toward a Theology of Dialogue', paper presented at a Consultation on Asian and African Contributions to Contemporary Theology, Ecumenical Institute, Bossey, 1976, pp. 3-11.

Ashcroft, B., Griffiths, G. \& Tiffins, H., 1989, Empire Writes Back: Theory and Practice in Post-Colonial Literatures, Routledge, London, UK. doi:10.4324/9780203426081

Awolalu, J.O., 1991, 'The encounter Between African Traditional Religion and other Religions in Nigeria', in J.K. Olupona (ed.), African Traditional Religion in Contemporary Society, pp. 30-40, Paragon House, St. Paul, MN.

Awolalu, J.O., 1979, Yoruba Beliefs and Sacrificial Rites, Longmans Group Ltd, London, UK.

Bahri, D., 1996, Introduction to Postcolonial Studies, viewed n.d. from, http://www. english.emory.edu/Bahri/Intro.htm

Bascom, W.R. \& Herskovits, M.J. (eds.), 1975, Continuity and Change in African Cultures, University of Chicago Press, Chicago, IL.

Bhabha, H., 1994, The Location of Culture, Routledge, New York.

Crafford, D., 1996, 'African Traditional Religions', in P. Meiring (ed.), A World of Religions (A South African Perspective) pp. 1-26, Kagisco Publishers, Pretoria.

Denis, P., 2006, 'The Rise of Traditional African Religion in Post -Apartheid South Africa', Missionalia, 34(2/3), 310-323.

Dickson, K. \& Ellingworth, P. (eds.), 1969, Biblical Revelation and African Beliefs, Orbis Books, New York.

Du Toit, C., 1998, 'African Spirituality and the Poverty of Western Religious Experience', Journal of Theology for Southern Africa 100, 36-60.

Dube, M., 2000, Postcolonial Feminist Interpretation of the Bible, Chalice Press, St Louis, MO.

Duncan, D., 2004, Postcolonial Theory, viewed n.d. from, http://www4.cord.edu/ projects/murphy/Postcolonial\%20Theory/

Fage, J.D. (ed.) 1970, Africa Discovers Her Past, Oxford University Press, London, UK.

Gort, J.D., 2008, 'The Search for Interreligious Convivance, ongoing challenge and charge' Verbum et Ecclesia 29(3), 744-763.

Grove, P.B., 1966, Webster's Third New International Dictionary of English Language, G. \& C. Merriam Co., Springfield, MA.

Hospital, C.G., 2007, 'Towards Maturity in Inter-Faith Dialogue', Crosscurrents, Fall, 356-364.

Hospital, C.G., 1973, African Traditional Religion: A Definition, SCM Press, London, UK. Idowu, B., 1962, Olodumare God in Yoruba Belief, Longmans of Nigerian Ltd, Lagos.

Isomae, J., 2006, 'The Study of Religion under Postcolonial Conditions', Bulletin/CSSR 35 (4).

Ikenga-Metuh, E. (ed.), 1991, African Religion in Western Conceptual Schemes: The Problem of Interpretation, Imico Books, Jos.

Kalilombe, P.A., 1981, 'The Salvific Value of African Religions', in G. H. Anderson \& T.F. Stransky (eds.), Mission Trends No 5, pp. 50-68, Wm B Eerdmans Publishing Co. Grand Rapids, MI.

Kayode, J.O, 1984, Understanding African Traditional Religion, University of Ife Press, Ile-Ife.

Knitter, P.F., 1995, One Faith, Many Religions: Multifaith Dialogue and Global Responsibility Orbis Books, Maryknoll, NY.

Mbiti, J.S., 1970, Concepts of God in Africa, SPC, London, UK.

Mercado, L.N., 2004/2005, 'The Change in Catholic Attitudes Towards Traditional Religion', Dialogue \& Alliance 18(2).

Mills, W., 1995, 'Missionaries Xhosa clergy and the suppression of African Traditional custom', in H. Bredencamp \& R. Ross (eds.), Mission and Christianity in South African History, pp. 153-175, University of Witwatersrand Press, Witwatersrand.

Muzorewa, G.H., 1985, The Origin and Development of African Theology, Orbis Books, Maryknoll, NY.

Muwahidah, S.S., 2008, 'Interfaith Dialogue at the Grassroots Level: A Case Study of An Interfaith Empowerment Programm in East Java, Indonesia', Political Theology, 99(1), 79-95.

Nkulu-N'Sengha, M., 1996, Journal of Ecumenical Studies, 33(4), 528-556.

Nyamiti, C., 1984, Christ as Our Ancestor: Christology from an African Perspective, Mambo Press, Gweru, Harare.

Oborji, F.A., 2002, 'In Dialogue with African Traditional Religion: New Horizon', Mission Studies 19(1), 37.

Olupona, J.K. \& Rey, T. (eds.), 2008, Orisa Devotion as World Religion, University of Wisconsin Press, Madison, WI.

Onwubiko, O., 1991, African Thought, Religion and Culture, Brigard Memorial Seminary, Enugu. 
Oxford University Press, 2000, Oxford Advanced Learner's Dictionary, 6th edn., Oxford University Press, Oxford, UK.

Semioticon, 2002, 'Postcolonialism Today: Theoretical Challenges and Pragmatic Issues', presented at a Multidisciplinary Conference, Toronto, September 26-28, 2002, viewed n.d. from, www.semioticon.com/postcol.htm

Said, E., 1978, Orientalim, Random Houselnc., New York.

Sidhom, S., 1969, 'The Theological Estimate of Man', in X. Dickson \& X. Ellingworth (eds.), Biblical Revelation and African Beliefs, pp. 83-115, Orbis Books, Maryknoll, NY.
Sugirtharajah, R.S., 2001, The Bible and the Third World: Precolonial, Colonial, and Postcolonial Encounters, Cambridge University Press, Cambridge, UK. doi:10.1017/ CBO9780511612619

Van der Walt, B.J., 2003, Understanding and Rebuilding Africa, The Institute for Contemporary Christianity in Africa, Potchesftroom.

Webster, 2005, Webster's Universal Dictionary and Thesaurus, Geddes \& Grossset, New Lanark, UK.

Wijsen, F., 2007, Seeds of Conflict in a haven of peace: From religious studies to interreligious studies in Africa, Editions Rodopi, Amsterdam. 